\title{
Nitrifying and denitrifying microbial communities and their relationship to nutrient fluxes and sediment geochemistry in the Derwent Estuary, Tasmania
}

\author{
G. C. J. Abell ${ }^{1, *}$, D. J. Ross ${ }^{2}$, J. P. Keane ${ }^{2}$, J. M. Oakes ${ }^{3}$, B. D. Eyre ${ }^{3}$, S. S. Robert ${ }^{1}$, \\ J. K. Volkman ${ }^{1}$ \\ ${ }^{1}$ CSIRO, Marine and Atmospheric Research and Wealth from Oceans, National Research Flagship, Hobart, Tasmania 7000, Australia \\ ${ }^{2}$ Institute for Marine and Antarctic Studies, University of Tasmania, Private Bag 49, Hobart, Tasmania 7001, Australia \\ ${ }^{3}$ Centre for Coastal Biogeochemistry, Southern Cross University, Military Road, Lismore, New South Wales 2480, Australia
}

\begin{abstract}
Mineralisation, nitrification and denitrification in sediments are key processes that contribute to the removal of nitrogen from coastal waters. Together these processes are important in preventing the buildup of nitrogen, which can lead to eutrophication in estuarine systems. Spatial and temporal patterns in the composition of nitrifier (bacterial [AOB] and archaeal ammonia oxidizers [AOA]; amoA), denitrifier (nirS) and total bacterial and archaeal (16S rRNA gene) communities in sediment from the Derwent Estuary in southeast Tasmania, Australia, were contrasted with key environmental parameters and benthic nutrient fluxes. Spatial and temporal factors were significant in terms of shaping microbial community composition. Organic matter composition ( $\mathrm{C}: \mathrm{N}$ isotope ratios, $\% \mathrm{~N}$ and $\% \mathrm{C}$ ) was significantly related to the abundance of the different microbial guilds. There was a significant correlation between both the sediment nitrogen content and carbon stable isotope ratio with community composition for total bacteria, AOA and denitrifiers. Sediment chlorophyll a was significantly associated with AOB composition and carbon isotope ratio was related to total archaeal community composition.
\end{abstract}

KEY WORDS: Nitrification - Denitrification - Estuarine sediment $\cdot$ Nutrient fluxes $\cdot$ Bacteria Archaea

\section{INTRODUCTION}

Nutrient enrichment is one of the most significant environmental risks to coastal waters around the world (Cloern 2001), including the Australian coast (Zann 1995, Harris et al. 1996, McCook 1999). Excessive nitrogen can lead to coastal eutrophication and hypoxic events, causing loss of biodiversity in benthic habitats, and consequent threats to fisheries (Cloern 2001). The risk of eutrophication depends on the relative weightings of input and removal processes and the composition of sediment organic matter $(\mathrm{OM})$, which is affected by both natural and anthropogenic inputs. The quantity and quality (lability) of $\mathrm{OM}$ in estuarine sediments influence the rate at which it is remineralized by microbial communities (Middelburg et al. 1996).

Following remineralisation, nitrogen can be removed by transport of nutrient-rich water offshore or through the microbially mediated anaerobic processes of anammox and denitrification, which effectively transfer nitrogen to the atmosphere (Harris et al. 1996). The process of ammonia oxidation, the conversion of ammonia to nitrite $\left(\mathrm{NO}_{2}^{-}\right)$in the presence of oxygen, provides the critical link between the initial respiration of $\mathrm{OM}$ and denitrification. 
Aerobic ammonia oxidation is carried out by the lithotrophic ammonia oxidizers, comprising the archaeal ammonia oxidizers (AOA) and bacterial ammonia oxidizers (AOB). These nitrifiers can be quantified and characterized by analysis of the amoA gene encoding the alpha-subunit of ammonia monooxygenase. Previous studies have demonstrated that sediment, the primary site of estuarine nitrification, may contain both $\mathrm{AOA}$ and $\mathrm{AOB}$, with some estuarine regions dominated by AOB (Mosier \& Francis 2008, Santoro et al. 2008) and others by AOA (Beman \& Francis 2006, Abell et al. 2010). The reason for the presence of one group of seemingly functionally equivalent groups over another in the environment is unclear, although it has been suggested that $\mathrm{pH}$ (Nicol et al. 2008), nitrite (Sahan \& Muyzer 2008), sulphide and phosphate (Erguder et al. 2009) and salinity (Mosier \& Francis 2008) may be important, whilst large variations in salinity, oxygen and hydrological factors may shape the structure of these communities (Stehr et al. 1995, Cébron et al. 2003, Francis et al. 2003, Dang et al. 2008, Abell et al. 2010, Abell et al. 2011).

Denitrification, the conversion of nitrate to gaseous forms including $\mathrm{N}_{2} \mathrm{O}$, a potent greenhouse gas, and dinitrogen gas, is carried out by a wide range of microorganisms and is estimated to remove around $8 \mathrm{Tg}$ of nitrogen from estuarine environments annually (Seitzinger et al. 2006). Denitrifying communities are commonly characterized by the genes encoding the cytochrome $c d_{1}$ and copper-containing nitrite reductases (nirs and nirK, respectively) (Philippot \& Hallin 2005).

Previous studies have demonstrated that nirS is the dominant nitrite reductase in estuarine sediments (Abell et al. 2010, Mosier \& Francis 2011). Denitrifier community abundance and composition (nirS) have been related to both potential denitrification (Mosier \& Francis 2011) and environmental variables including large ranges in salinity and chlorophyll a ( $\mathrm{chl} \mathrm{a}$ ) (Abell et al. 2010, Mosier \& Francis 2011).

The aims of the present study were to assess the effect of spatial and temporal factors on the abundance and diversity of nitrifying, denitrifying and total microbial communities in the Derwent Estuary, southeast Tasmania, Australia, and to examine the relationship between the abundance and diversity of nitrifying, denitrifying microbial communities and environmental variables and nutrient fluxes measured at the same sampling sites. As a result of this research, we hope to further understand the link between these microbial groups, sediment geochemistry and estuarine nitrogen cycling and the effect that increasing anthropogenic inputs can have on these.

We hypothesized that the structure and abundance of N-cycling microbial communities would reflect the individual site sediment properties and that sediment biogeochemistry would, in turn, reflect microbial communities.

\section{MATERIALS AND METHODS}

\section{Study sites and sample collection}

The Derwent Estuary is a microtidal, stratified temperate estuary in southern Tasmania, Australia; it is $187 \mathrm{~km}$ in length and has a catchment of $1427 \mathrm{~km}^{2}$. The estuary is influenced by fluctuating flow regimes (due to variable rainfall and changing requirements for water for hydroelectric generation and irrigation) and nutrient inputs (agriculture run-off, marine inflows, sewerage and wastewater treatment plants, and a paper mill).

Three sites were selected from the middle (S1, S2 and S3) and lower (S4, S5 and S6) regions of the Derwent Estuary (Fig. 1). The 2 regions were chosen because they represent different environmental conditions (hydrodynamics, salinity, sediment grain size, contaminant levels, etc.; see Green \& Coughanowr 2003), which may influence their microbial ecology and $\mathrm{N}$ cycling. To assess the relative importance of temporal variation, the survey was performed 3 times, during summer 2008, winter 2008 and summer 2009 (T1, T2 and T3, respectively).

All sampling was carried out over unvegetated subtidal soft sediment; sampling during each of the

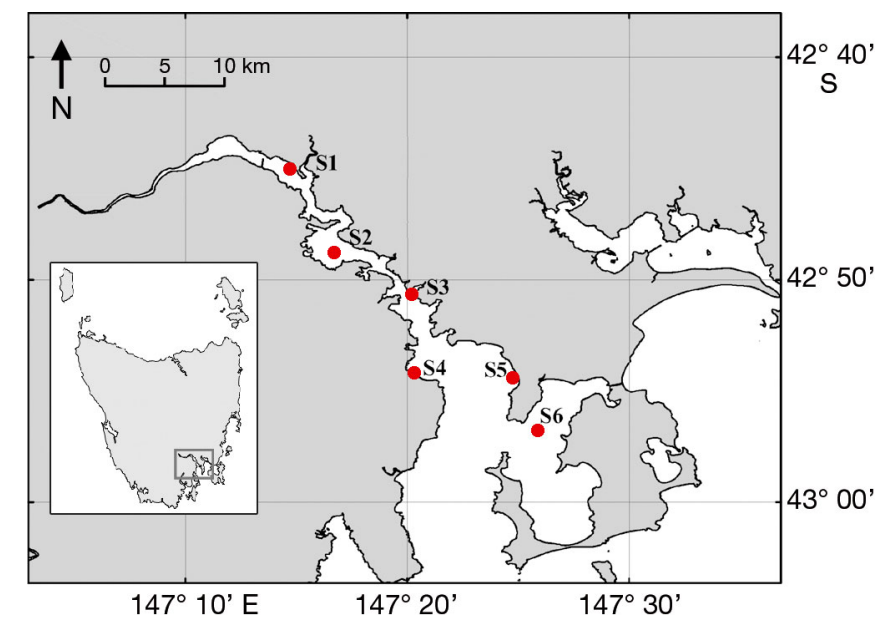

Fig. 1. Derwent Estuary, Tasmania, Australia, showing the location of the sampling sites used during this study (S1-S6) 
time points was completed over the course of $1 \mathrm{wk}$. Dissolved oxygen (DO) saturation, temperature and salinity were measured at each site on each sampling occasion using a HACH (HQ40d) dual-input multiparameter digital meter with optical DO (LDO10115) and conductivity probes (CDC401-15) (Hach Company).

\section{Microbial samples}

Divers collected sediment cores (50 mm diameter) in triplicate from each site at each time for the assessment of microbial composition and abundance. The top $10 \mathrm{~mm}$ of sediment was sub-sampled into a sterile $50 \mathrm{ml}$ centrifuge tube and immediately frozen using liquid nitrogen, transported to the laboratory and stored at $-80^{\circ} \mathrm{C}$ until further processing.

\section{Benthic flux samples}

At each site, divers collected 5 intact sediment cores $(30 \times 14.5 \mathrm{~cm}$ inner diameter) randomly by pushing core cylinders into the sediment. The cores were transported to the laboratory within $4 \mathrm{~h}$ in bins of site water at ambient temperature. Site water for replacement of water during incubations was collected from just above the sediment surface using a bilge pump.

In the laboratory, cores were placed in temperature-controlled holding tanks (100 l) that were slowly filled with site water, avoiding sediment resuspension, and incubated at in situ light levels $( \pm 5.0 \%)$ and temperature $\left( \pm 2^{\circ} \mathrm{C}\right)$ over a $12 \mathrm{~h}$ light: $12 \mathrm{~h}$ dark cycle. The cores were covered with transparent lids with rotating discs $(11 \times 1.2 \mathrm{~cm}$ at $14 \mathrm{rpm})$ that allowed a free exchange of water between the cores and the holding tank. This stirring set-up allowed us to create homogeneous hydrodynamic conditions over the cores' sediment surface (Glud et al. 1995, Tengberg et al. 2004).

\section{Flux measurements}

Rates of nutrient exchange were measured during a dark incubation on the second day following sampling. Before the commencement of the flux measurements, the cores were flushed with fresh site water and capped. Water samples $(\sim 250 \mathrm{ml})$ were collected with syringes at the start and end of each of the incubations $(\sim 4 \mathrm{~h})$. DO did not drop to more than $20 \%$ below ambient concentrations. Filtered
(0.45 $\mu \mathrm{m}$ membrane) samples were taken for measurements of total dissolved nitrogen, total dissolved phosphorus, ammonium $\left(\mathrm{NH}_{4}{ }^{+}\right)$, nitrite $\left(\mathrm{NO}_{2}\right)$, nitrate $\left(\mathrm{NO}_{3}\right)$, phosphate $\left(\mathrm{PO}_{4}\right)$, silicate $\left(\mathrm{SiO}_{4}\right)$ and alkalinity. Nutrient samples were frozen in polypropylene screw cap bottles until required for analysis.

Net flux rates were calculated in units of $\mathrm{mmol} \mathrm{m}^{-2}$ $\mathrm{d}^{-1}$ using:

$$
\text { Flux }=(\Delta C / \Delta T) \times(V / A)
$$

where $\Delta C$ is the change in concentration of solute $\left(\mathrm{mmol} \mathrm{l}^{-1}\right), \Delta T$ is the duration of incubation (d), $V$ is the volume of water enclosed (l) and $A$ is the core sediment area $\left(\mathrm{m}^{2}\right)$.

\section{Sediment properties}

At the end of the incubation, $10 \mathrm{~g}$ of surface sediment (upper $10 \mathrm{~mm}$ ) was collected from each core for sediment $\mathrm{C}: \mathrm{N}$ and stable isotope analysis and stored at $-20^{\circ} \mathrm{C}$ prior to analysis. Microphytobenthos biomass (measured as chl a) was determined using a $90 \%$ acetone extraction of the upper $10 \mathrm{~mm}$ of each core. An acidification step was used to separate degradation products from chl a (Strickland \& Parsons 1972). For sediment particle size analysis, the sediment was passed wet through a graded series of sieves $(4 \mathrm{~mm}, 2 \mathrm{~mm}, 1 \mathrm{~mm}, 500 \mu \mathrm{m}, 250 \mu \mathrm{m}, 150 \mu \mathrm{m}$ and $63 \mu \mathrm{m}$ ). The sediment retained on each sieve was dried and weighed and the percentage of total sample weight was calculated. The fraction $<63 \mu \mathrm{m}$ was determined as the difference between initial sample weight and combined weight of the remaining fractions. For analysis of stable isotopes and C:N, freezedried, homogenized, ground subsamples of ovendried $\left(60^{\circ} \mathrm{C}\right)$ sediment were weighed into silver capsules for $\delta^{13} \mathrm{C}$ analysis following acidification (1 M $\mathrm{HCl}$ ) and into tin capsules for $\delta^{15} \mathrm{~N}$ analysis.

\section{Analytical techniques}

\section{Nutrients}

All nutrient analyses were carried out colourimetrically using a Lachat Flow Injection Analyser. $\mathrm{NO}_{2}$ was determined using sulphanilamide, and oxidized nitrogen $\left(\mathrm{NO}_{\mathrm{x}}\right)$ was determined by cadmium reduction. $\mathrm{NH}_{4}{ }^{+}$was determined using hypochlorite/ phenolate, and dissolved inorganic nitrogen was determined as the sum of $\mathrm{NO}_{\mathrm{x}}$ and $\mathrm{NH}_{4}{ }^{+}$(Eyre \& Ferguson 2005). 


\section{Isotopes}

Sediment $\delta^{13} \mathrm{C}, \delta^{15} \mathrm{~N}, \% \mathrm{C}$ and $\% \mathrm{~N}$ were determined using a Thermo Finnigan Flash EA 112 interfaced via a Thermo Conflo III with a Thermo Delta V Plus IRMS (Oakes et al. 2010). Samples of acetanilide of known isotope composition were analysed within each run to verify isotope values. Reproducibility for both $\delta^{13} \mathrm{C}$ and $\delta^{15} \mathrm{~N}$ was $\pm 0.2 \%$.

\section{Molecular analysis}

Immediately following thawing, sediment samples were homogenised using a spatula, and DNA was extracted and quantified as previously described (Abell et al. 2010). The $a m o A$, nirs and 16S rRNA genes were amplified from DNA extractions using the primers and cycling conditions described in Table S1 in the Supplement at www.int-res.com/articles/suppl/ a070p063_supp.pdf. Template comprised $2 \mu \mathrm{l}$ DNA extract (20 to $50 \mathrm{ng}$ ) and products were amplified in triplicate to reduce the effects of PCR drift.

PCR amplifications comprised 1 unit of Taq polymerase (Invitrogen), $12.5 \mu \mathrm{l}$ of Failsafe PCR master mix G (Epicentre) and $12.5 \mathrm{pmol}$ of each primer in a total volume of $25 \mu \mathrm{l}$. PCR was performed using an Eppendorf thermal cycler with 1 cycle of $5 \mathrm{~min}$ at $95^{\circ} \mathrm{C}$, followed by 30 cycles of: 1 min denaturation at $95^{\circ} \mathrm{C}, 1 \mathrm{~min}$ annealing with a reduction in annealing temperature of $0.5^{\circ} \mathrm{C}$ per step for the first 20 steps, then at the specified annealing temperature for the primer (Table 1) and 1 min extension at $72^{\circ} \mathrm{C}$, followed by a single extension step of $4 \mathrm{~min}$ at $72^{\circ} \mathrm{C}$.

Bacterial and archaeal amoA, nirS and bacterial and archaeal 16S rRNA genes were quantified from DNA extractions using a 7500 real-time PCR system (Applied Biosystems). Quantification of denitrifiers in the present study used nirS as a marker because pre-

Table 1. Site characteristics at the time of each sampling (T1, T2 or T3). Temperature, salinity and dissolved oxygen (DO) were measured in the bottom water

\begin{tabular}{|c|c|c|c|c|c|c|c|c|c|c|}
\hline \multirow[t]{2}{*}{ Site } & \multirow{2}{*}{$\begin{array}{l}\text { Depth } \\
\text { (m) }\end{array}$} & \multicolumn{3}{|c|}{ Temperature $\left({ }^{\circ} \mathrm{C}\right)$} & \multicolumn{3}{|c|}{$-\mathrm{DO}(\%)-$} & \multicolumn{3}{|c|}{-Salinity } \\
\hline & & $\mathrm{T} 1$ & $\mathrm{~T} 2$ & T3 & $\mathrm{T} 1$ & $\mathrm{~T} 2$ & T3 & $\mathrm{T} 1$ & $\mathrm{~T} 2$ & T3 \\
\hline \multicolumn{11}{|c|}{ Mid estuary } \\
\hline S1 & 4.2 & 17.6 & 9.8 & 17.2 & 69.1 & 84.3 & 47.8 & 25.6 & 28 & 24.0 \\
\hline $\mathrm{S} 2$ & 3.5 & 17.8 & 10.6 & 17.1 & 68.8 & 79.9 & 70.5 & 33 & 33 & 28.1 \\
\hline S3 & 9.0 & 17.9 & 10.9 & 16.1 & 75.9 & 85 & 79.9 & 35 & 34.5 & 33.7 \\
\hline \multicolumn{11}{|c|}{ Lower estuary } \\
\hline $\mathrm{S} 4$ & 12.9 & 18.2 & 10.8 & 16.1 & 68.8 & 87.5 & 77.9 & 35.3 & 34 & 35.1 \\
\hline S5 & 12.1 & 18.2 & 10.8 & 16.1 & 70.6 & 86.6 & 83.0 & 35.3 & 34.1 & 34.9 \\
\hline S6 & 10.7 & 18.1 & 11.1 & 17.0 & 78.2 & 51 & 63.1 & 35 & 34.6 & 35.4 \\
\hline
\end{tabular}

vious work demonstrated that nirK was substantially less abundant at all sites in the Derwent Estuary (data not shown). PCR reactions (15 $\mu \mathrm{l})$ comprised $10 \mu \mathrm{g} \mu \mathrm{l}^{-1}$ bovine serum albumin, $10 \mathrm{pmol}$ of each primer, $7.5 \mu \mathrm{l}$ of Q-PCR master mix (Applied Biosystems) and $1 \mu \mathrm{l}$ of template DNA. Fluorescence acquisition was performed at the temperatures indicated for each gene in Table S1, at which temperature all primer dimers had melted, but specific products had not. The cycling conditions were $95^{\circ} \mathrm{C}$ for $3 \mathrm{~min}$, followed by 40 cycles of $40 \mathrm{~s}$ at $95^{\circ} \mathrm{C}, 30 \mathrm{~s}$ at the specific annealing temperature followed by $1 \mathrm{~min}$ at $72^{\circ} \mathrm{C}$ and then $20 \mathrm{~s}$ at the appropriate acquisition temperature (Table S1). Standards for qPCR were generated by serial dilutions of known copies of PCR fragments of the respective functional gene generated using M13 PCR from clones generated during the present and previous studies (data not shown). Samples were assayed as previously described (Abell et al. 2010) to ensure that there was no significant effect of PCR inhibition on the qPCR data.

Terminal Restriction Fragment Length Polymorphism (T-RFLP) analysis of each gene was performed as described previously (Abell et al. 2010) using the Taq-I enzyme (New England Biolabs) and FAMlabeled forward primers described in Table S1. Profiles were analysed using the GeneMapper 3.7 package (Applied Biosystems).

\section{Statistical analysis}

For univariate analysis of the differences in nutrient fluxes, sediment physical parameters and gene abundances, data were checked for normality and homogeneity of variances using $\mathrm{Q}-\mathrm{Q}$ and residual plots. Data not meeting the assumptions of ANOVA were log-transformed (square root for gene abundances and reciprocal for fluxes). Significant factors returned from the 2-way ANOVA were compared using Tukey's honestly significant difference post hoc tests. Relationships between individual nutrient fluxes, environmental parameters, sediment composition and gene abundances were determined using Spearman's rank order correlation (Fig. S1 in the Supplement). Stepwise multiple linear regression was performed to identify the sediment properties that were most predictive for the abundance of different microbial groups. The QPCR abundance of marker genes was used as a dependent variable whilst \%C, 
$\% \mathrm{~N}, \mathrm{C}: \mathrm{N}, \delta^{15} \mathrm{~N}, \delta^{13} \mathrm{C}$, chl $a, \mathrm{DO}$, temperature and salinity were used as independent variables. Variables were excluded when they correlated significantly with other variables (Fig. S1). Due to the large number of predictor variables being tested, only the first 2 variables selected by the model were used so as to avoid over fitting the model. All univariate tests (at $\alpha=0.05$ ) and graphing were performed using the $\mathrm{R}$ programming environment (www.r-project.org).

Analysis of the richness, diversity and evenness of different genes was conducted using the DIVERSE function in Primer 6. The Shannon diversity index $\left(H^{\prime}\right)$ and the total number of T-RFs $(S)$ were analysed to give a metric of the diversity of Operational Taxonomic Units (OTUs) (T-RFLP peaks), with greater values indicating higher diversity. Pielou's evenness $\left(J^{\prime}\right)$ was calculated and given a measure of the distribution of peaks within the T-RFLP profile, with values close to 1 indicating an even community (similar numbers of each OTU), whilst values close to 0 indicated a community dominated by relatively few of its members.

Multivariate ANOVA between T-RFLP profiles was performed using the PERMANOVA+ package for Primer 6 software (PRIMER-E). Relatedness of different gene profiles for each sample was calculated using the Bray-Curtis similarity calculation on standardised data (Kenkel \& Orloci 1986, Minchin 1987).

Spatial effects (site and section) and temporal effects (time) were tested using permutation-based testing of multivariate analysis of variation (PERMANOVA) using approaches described previously (Anderson et al. 2008). The PERMANOVA model used a 3-way factorial design using the factors: section (fixed, 2 levels), time (random, 3 levels) and site (random, nested within section and time, 6 levels). Default settings for PERMANOVA were used (Type III sums of squares, 9999 permutations, permutations of residuals under a reduced model). All tests were conducted at $p<0.05$. Pairwise comparisons were conducted post hoc on factors found to be significant in the 'global' test.

The structural similarity of T-RFLP data sets between different genes was assessed through the generation of a Mantel correlation of Bray-Curtis similarity matrices using the RELATE function (Spearman correlation, 9999 permutations) in Primer 6 (PRIMERE), with the null hypothesis that there is no similarity between the assemblage patterns for each of the genes (tested at $\mathrm{p}=0.05$ ).

Multi-dimensional scaling (MDS) plots based on a Bray-Curtis similarity matrix of T-RFLP profiles were generated using the vegan package in R (www.r- project.org). Significant relationships between environmental and nutrient flux variables and ordination were determined, based on 9999 permutations, using the envfit function. Significant relationships between ordination and environmental variables were plotted as vectors, whereby the vector indicates the direction of the gradient of the environmental variable and the length indicates the correlation between the ordination and the environmental variable. Significant relationships between nutrient flux variables returned from the envfit routine $(\mathrm{p}<0.05)$ and MDS ordination of the respective genes were illustrated as overlaid topography using the ordisurf function.

\section{RESULTS}

\section{Sampling and physical analysis}

Salinity in bottom waters was slightly lower in the mid estuary compared with the lower estuary, due to mixing of inflowing marine water with outflowing fresh waters $(p<0.05)$. The lowest salinity recorded during the study was 24.0 at Site S1 at Time T3, which corresponded with the highest monthly rainfall and flow rates during the 3 sampling times (data not shown). Temperature was significantly different in the estuary for each of the sampling times (all $\mathrm{p}<$ 0.001; Table 1).

Sediment \%C, \% N and chl $a$ and bottom water DO (Table S2 in the Supplement) did not vary significantly between estuary sections or among sampling times during the study. Sediment $\delta^{15} \mathrm{~N}$ and $\delta^{13} \mathrm{C}$ values were, however, significantly depleted in the middle estuary compared with the lower estuary $\left(\delta^{15} \mathrm{~N}: \mathrm{p}<0.001 ; \delta^{13} \mathrm{C}: \mathrm{p}<0.05,0.01\right.$ and 0.001 for $\mathrm{T} 1$, $\mathrm{T} 2$ and T3, respectively). This difference in sediment OM was also reflected in $\mathrm{C}: \mathrm{N}$ ratios, with lower $\mathrm{C}: \mathrm{N}$ in the lower estuary consistent with more labile (i.e. algal) material compared with the mid estuary ( $p<$ $0.05)$ signal of more recalcitrant terrestrial OM. Sediment $\mathrm{C}: \mathrm{N}$ was also higher in the whole estuary at $\mathrm{T} 3$ than T2 $(p<0.05)$.

\section{Nutrient fluxes}

Nutrient flux measurements were performed under both light (results not shown) and dark conditions. All sites were net respiratory, with mean oxygen consumption exceeding oxygen production; as such, only dark fluxes were included in the analysis. Sediment oxygen uptake was between 320 and 
$1900 \mu \mathrm{mol} \mathrm{m} \mathrm{m}^{-2} \mathrm{~h}^{-1}$. Oxygen fluxes were similar for both estuary sections, but were significantly lower at $\mathrm{T} 2$ than T1 or T3 $(p<0.05)$. This difference was concomitant with the lower temperatures recorded for the estuary, as demonstrated by the negative correlation between $\mathrm{O}_{2}$ flux and temperature (Fig. S1). Fluxes of $\mathrm{NO}_{\mathrm{x}}$ and $\mathrm{NH}_{4}$ (Fig. 2) varied with sampling time but were not significantly different between estuary sections. Sites acted as both a source and a sink of $\mathrm{NO}_{\mathrm{x}}$ and $\mathrm{NH}_{4}$ at different times during the study. The mean flux of $\mathrm{NO}_{\mathrm{x}}$ at each site (Fig. 2) was highest $\left(159 \mu \mathrm{mol} \mathrm{m}{ }^{-2} \mathrm{~h}^{-1}\right)$ in the mid estuary at T1 and lowest in the mid estuary at T3 $\left(-47 \mu \mathrm{mol} \mathrm{m}^{-2}\right.$ $\mathrm{h}^{-1}$ ). Overall, there was a significantly higher flux of $\mathrm{NO}_{\mathrm{x}}$ across the whole estuary at T1 compared with the other times $(\mathrm{p}<0.05) . \mathrm{NH}_{4}$ flux was also highest in the middle estuary at T1 $\left(132 \mu \mathrm{mol} \mathrm{m}{ }^{-2} \mathrm{~h}^{-1}\right)$ and was lowest in the lower estuary at T2 $\left(-44 \mu \mathrm{mol} \mathrm{m}^{-2}\right.$ $\mathrm{h}^{-1}$ ), but there was no significant difference in $\mathrm{NH}_{4}$ flux with section or time.
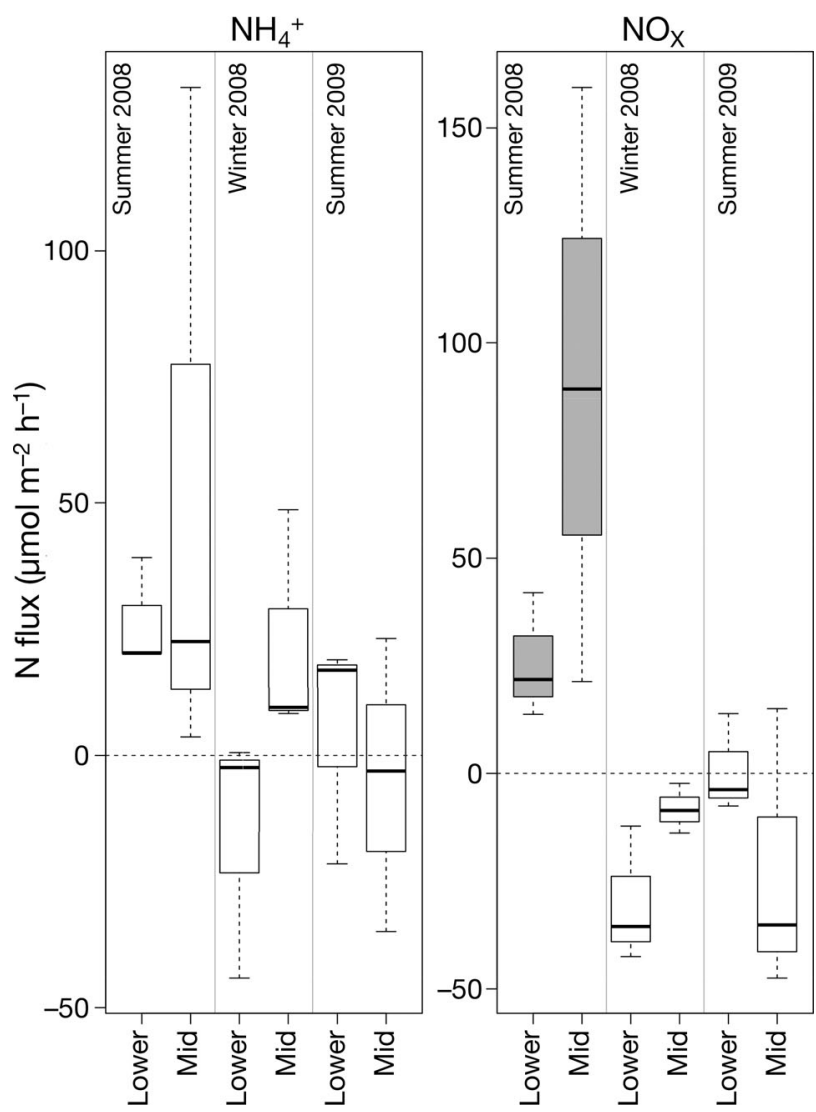

Fig. 2. Ammonium $\left(\mathrm{NH}_{4}^{+}\right)$and nitrate + nitrite $\left(\mathrm{NO}_{\mathrm{x}}\right)$ fluxes in the lower and middle Derwent Estuary at the 3 sampling times. Values $>0$ indicate a sediment to water column flux and values $<0$ indicate a water column to sediment flux. Significant differences between times for $\mathrm{NO}_{\mathrm{x}}$ fluxes are indicated by shading $(\mathrm{p}<0.05)$

\section{Gene abundance}

The abundance of bacterial 16S varied between 1.6 $\times 10^{9}$ and $1.6 \times 10^{10}$ copies ${ }^{-1}$ dry weight (DW) sediment, whilst archaeal $16 \mathrm{~S}$ varied between $1.3 \times 10^{7}$ and $4.7 \times 10^{8}$ copies g $^{-1}$ DW (Fig. 3). Overall, bacterial and archaeal $16 \mathrm{~S}$ were both significantly more abundant in the lower estuary $(p<0.05)$ compared with the mid estuary.

None of the functional genes assayed varied significantly in abundance between times or estuarine sections. Mean bacterial amoA abundance across individual sites varied between $1.1 \times 10^{7}$ and $1.1 \times$ $10^{9}$ copies $\mathrm{g}^{-1} \mathrm{DW}$ whilst archaeal amoA varied between $7.7 \times 10^{6}$ and $7.2 \times 10^{7}$ copies $\mathrm{g}^{-1}$ DW (Fig. 4). Bacterial amoA was more abundant than archaeal $a m o A$ at 14 out of 18 of the sampling points. The ratio of bacterial to archaeal amoA varied between 0.3 and 71 . The abundance of nirS varied between $3.9 \times 10^{8}$ and $3.1 \times 10^{9}$ copies $\mathrm{g}^{-1}$ DW (Fig. 4).
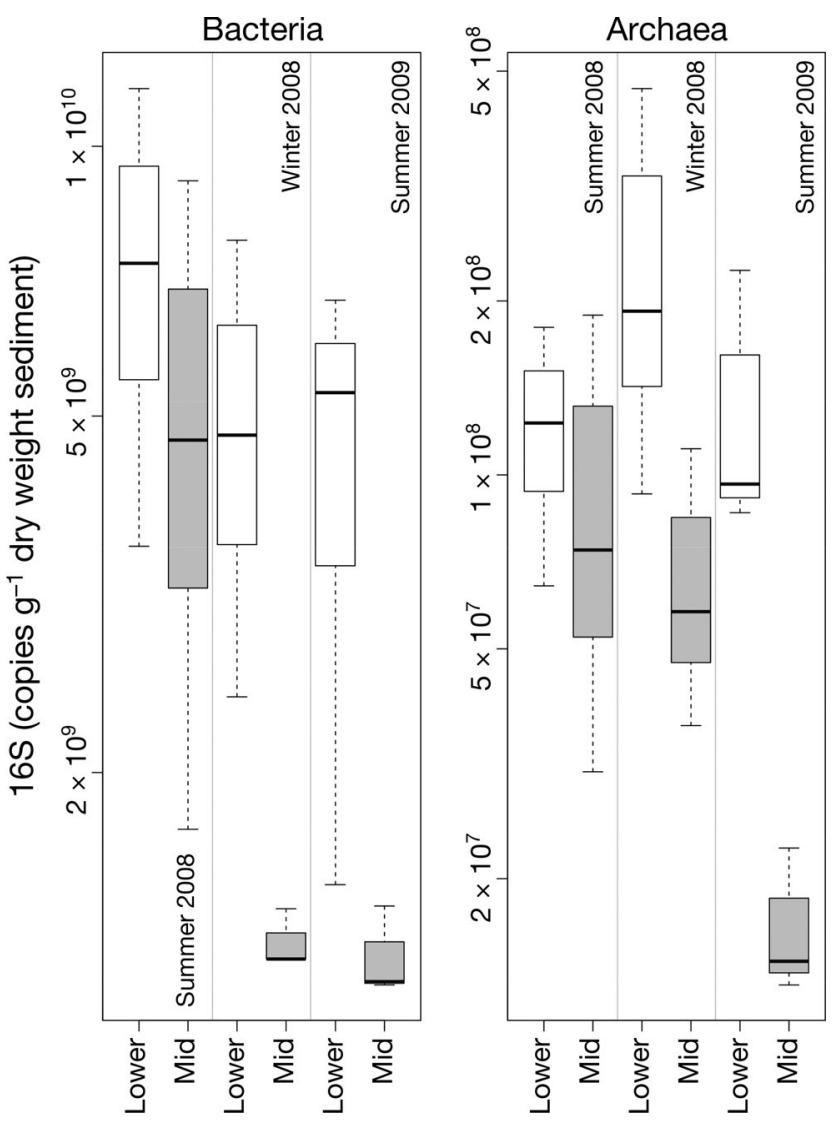

Fig. 3. 16S rRNA gene abundance, in the lower and middle Derwent Estuary during the 3 sampling times, representing total archaeal and bacterial abundances. Significant differences between sections are indicated by shading $(\mathrm{p}<0.05)$ 


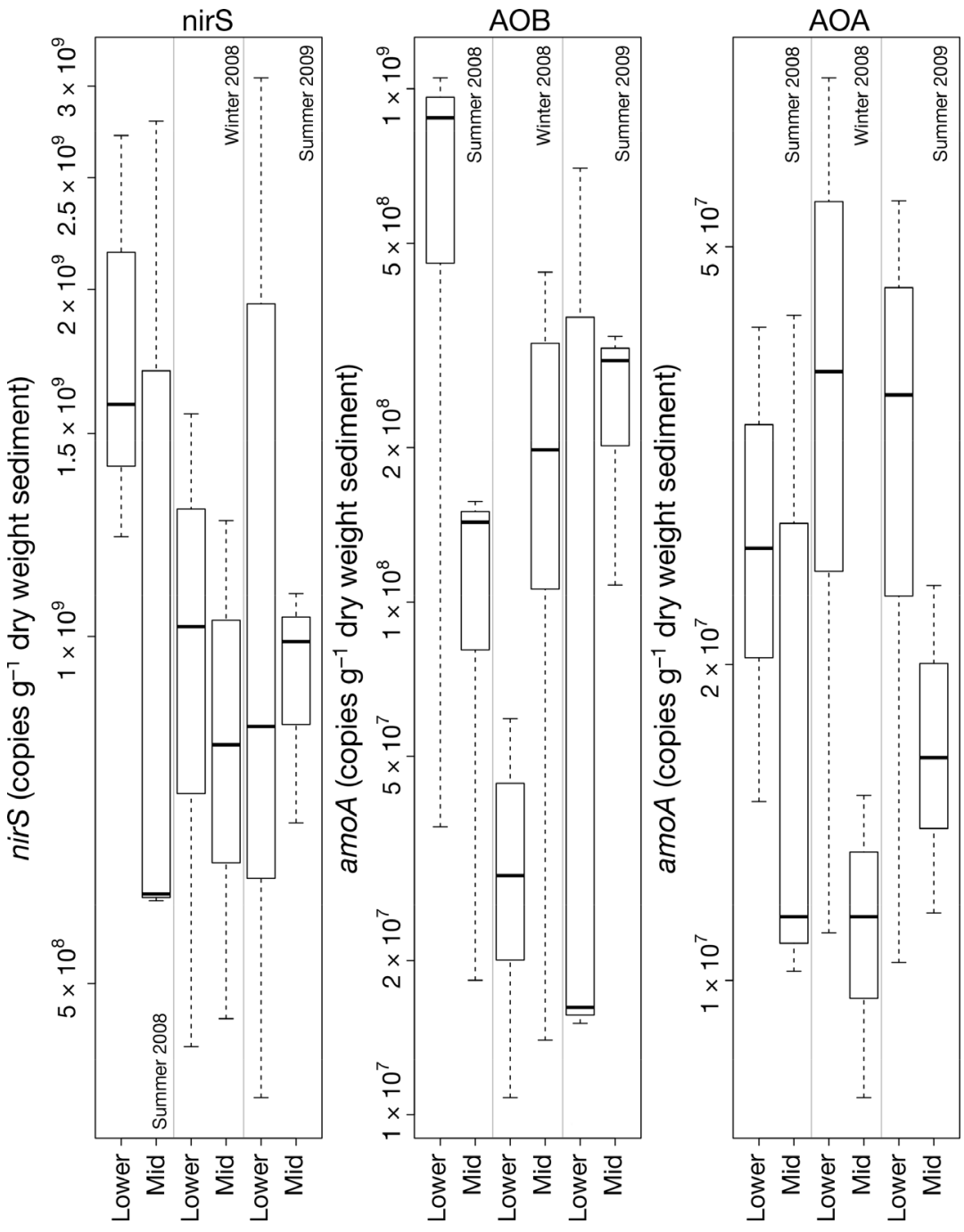

Fig. 4. Functional marker gene abundance, in the lower and middle Derwent Estuary during the 3 sampling times, of nirS (nirS), bacterial amoA (AOB) and archaeal amoA (AOA)

\section{T-RFLP analysis}

T-RFLP profiles for each gene showed variation in the number of T-RFs detected $(S$; number of peaks $>1.5 \%$ total peak area for that profile) and Shannon diversity index $\left(H^{\prime}\right)$ with highest values of each for bacterial 16S and lowest for AOB (35 and 14, respectively, for $S$ and 2.5 and 1.6 for $H^{\prime}$ ). The highest mean evenness $\left(J^{\prime}\right)$ was for nirs and AOA and the lowest for AOB. Diversity measures are shown in detail in Table S3 in the Supplement.

PERMANOVA demonstrated a significant effect of estuarine site on the composition of all genes examined $(\mathrm{p}<0.001)$. Despite variation in water column conditions (temperature, salinity and dissolved oxygen) between time points (Table 1), there was an effect of sampling time only on the composition of AOA
( $\mathrm{p}<0.001)$; there was also a significant effect of estuarine section on AOA and nirs community composition $(\mathrm{p}<0.02$ and $\mathrm{p}<0.05$, respectively; Table 2). There was no interacting effect of time and section on any of the genes examined. Only the AOA and nirS denitrifiers demonstrated larger scale patterns in spatial distribution whereby the variation in communities within the estuary sections was smaller than the variation between them (Table 2).

\section{Relationships between nutrient fluxes, abiotic parameters, environmental variables and gene abundance}

The present study revealed correlations between gene abundances, community composition and specific environmental parameters (summarised in Fig. S1). To examine these in more detail, multiple linear regression was used to determine the sediment characteristics that were the best predictors for abundance of the different genes (Table S3). Only variables that were not significantly correlated (Fig. S1) were used $\left(\delta^{15} \mathrm{~N}, \% \mathrm{~N}, \% \mathrm{C}\right.$, temperature and DO).

Sediment $\delta^{15} \mathrm{~N}$ and $\% \mathrm{C}$ together were the best predictors of both bacterial and archaeal $16 \mathrm{~S}$ abundance, accounting for 47 and $52 \%$ of the variability, respectively.

Bacterial amoA abundance was best accounted for by $\% \mathrm{~N}$ and $\% \mathrm{C}$, which together explained $42 \%$ of the variability, whilst $\delta^{15} \mathrm{~N}$ and $\% \mathrm{C}$ accounted for $60 \%$ of the variability of archaeal amo $A$ abundance. None of the factors tested accounted substantially for the abundance of nirS, with the best model $(\% \mathrm{~N})$ accounting for only $28 \%$ of the variability, possibly reflecting the widespread ability to denitrify across phylogenetically different taxa.

\section{Relationship between community composition and environmental variables}

Comparison of diversity indices with the chemical parameters indicated that the diversity of both total bacteria and AOA was strongly associated with the 
Table 2. Results of PERMANOVA testing the effects of estuary site, section (spatial) and time (temporal) on the community composition (T-RFLP profiles) of the different genes. CV $(\sqrt{ })$ denotes the square root of the component of variation (Anderson et al. 2008), a measure of the effect size in units of the community dissimilarities. Significant effects $(p<0.05)$ are given in bold

\begin{tabular}{|lcccccccccc|}
\hline \multirow{2}{*}{ Gene } & \multirow{2}{*}{ Residual } & \multicolumn{2}{c}{ Site } & \multicolumn{3}{c}{ Section } & \multicolumn{3}{c}{ Time } & \multicolumn{3}{c|}{ Section $\times$ Time } \\
& & CV $(\sqrt{ })$ & $p$ & $C V(\sqrt{ })$ & $p$ & $C V(\sqrt{ })$ & $p$ & $C V(\sqrt{ })$ & $p$ \\
\hline Arch 16S & 22.83 & $\mathbf{2 3 . 8 5}$ & $\mathbf{0 . 0 0 0 1}$ & 10.0 & 0.10 & 6.09 & 0.25 & -12.35 & 0.91 \\
Bact 16S & 12.21 & $\mathbf{1 3 . 7 0}$ & $\mathbf{0 . 0 0 0 1}$ & 16.47 & 0.09 & 2.11 & 0.36 & -5.35 & 0.75 \\
AOA amoA & 42.02 & $\mathbf{2 4 . 0 9}$ & $\mathbf{0 . 0 0 0 1}$ & $\mathbf{2 7 . 9 5}$ & $\mathbf{0 . 0 1 7}$ & $\mathbf{1 9 . 3 6}$ & $\mathbf{0 . 0 0 1}$ & 5.9 & 0.34 \\
AOB amoA & 37.04 & $\mathbf{2 5 . 7 2}$ & $\mathbf{0 . 0 0 0 1}$ & 21.09 & 0.091 & 12.08 & 0.064 & -13.48 & 0.91 \\
nirS & 15.17 & $\mathbf{1 4 . 3 6}$ & $\mathbf{0 . 0 0 0 1}$ & $\mathbf{2 0 . 3 7}$ & $\mathbf{0 . 0 4 8}$ & 5.39 & 0.15 & 3.57 & 0.33 \\
\hline
\end{tabular}

and $C: N\left(r^{2}=0.50, p=0.01\right)$, with isotope ratios and salinity higher in the lower estuary samples and C:N higher in the mid estuary samples (Fig. 6).

Analysis of bacterial and archaeal amoA profiles demonstrated that AOA community composition was significantly related to salinity $\left(\mathrm{r}^{2}=\right.$ $0.58, \mathrm{p}=0.001), \delta^{15} \mathrm{~N}\left(\mathrm{r}^{2}=0.72, \mathrm{p}=\right.$ $0.002)$ and $\delta^{13} \mathrm{C}\left(\mathrm{r}^{2}=0.64, \mathrm{p}=\right.$ $0.001)$, with all 3 parameters higher in the lower estuary sites. The AOB community composition was signifcontent and its source $\left(\delta^{15} \mathrm{~N}\right.$ values; Fig. S1) of sediment nitrogen.

Comparison of the ordination with environmental parameters from the same samplings indicated a number of significant relationships $(\mathrm{p}<0.05)$ between T-RFLP gene profiles and environmental factors (Figs. $5 \& 6$ ). There was a significant relationship between $\delta^{13} \mathrm{C}$ of sediment $\mathrm{OM}$ and the structure of the total archaeal community $\left(\mathrm{r}^{2}=0.46, \mathrm{p}=0.01\right.$; Fig. 5). There was also a significant relationship between the total bacterial community and salinity $\left(\mathrm{r}^{2}=0.55, \mathrm{p}=0.004\right), \delta^{15} \mathrm{~N}\left(\mathrm{r}^{2}=0.86, \mathrm{p}=0.001\right)$ and $\delta^{13} \mathrm{C}\left(\mathrm{r}^{2}=0.37, \mathrm{p}=0.05\right.$; Fig. 5).

The structure of nirS denitrifier communities was significantly related to salinity $\left(\mathrm{r}^{2}=0.43, \mathrm{p}=0.012\right)$, $\delta^{15} \mathrm{~N}\left(\mathrm{r}^{2}=0.88, \mathrm{p}=0.001\right), \delta^{13} \mathrm{C}\left(\mathrm{r}^{2}=0.61, \mathrm{p}=0.001\right)$ icantly related to $\mathrm{chl}$ a concentration $\left(\mathrm{r}^{2}=0.39, \mathrm{p}=\right.$

Comparison of the structure of functional gene data sets (RELATE analysis; Table S4 in the Supplement) demonstrated a significant relationship between all of the T-RFLP similarity matrices $(p<0.05)$. The greatest similarity $\left(\mathrm{r}^{\mathrm{S}}=0.64\right.$ in assemblage structure was between the denitrifiers (nirS) and the total bacterial community (bacterial 16S). The lowest similarity $\left(\mathrm{r}^{\mathrm{S}}=0.16\right)$ was between AOA and total archaea (archaeal 16S), suggesting that the majority of archaea are unrelated to the AOA. There was a significant similarity between $\mathrm{AOB}$ and $\mathrm{AOA}\left(\mathrm{r}^{\mathrm{S}}=0.45\right)$; however, this value was close to that between denitrifiers (nirS) and AOA $\left(\mathrm{r}^{\mathrm{S}}=0.51\right)$ Comparison of the T-RFLP profiles of the individual genes with the cor0.04; Fig. 6).
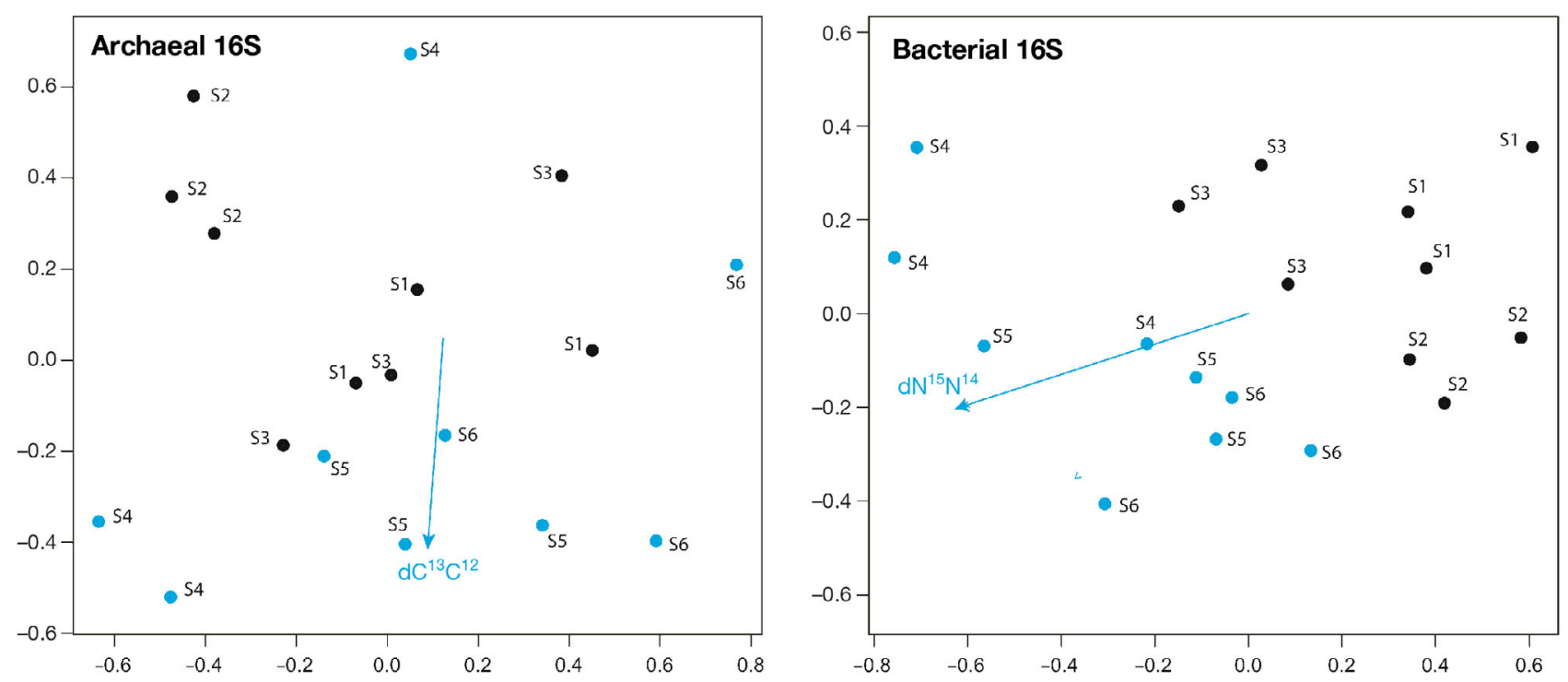

Fig. 5. Multi-dimensional scaling analysis of mean (site) archaeal (left) and bacterial (right) 16S rRNA T-RFLP profiles, showing sites in the mid estuary (black) and lower Derwent Estuary (blue). Significant relationships $(\mathrm{p}<0.05)$ between environmental variables and ordination are shown as vectors. Stress values for the archaeal and bacterial ordination were 16.5 and $12.6 \%$, respectively 

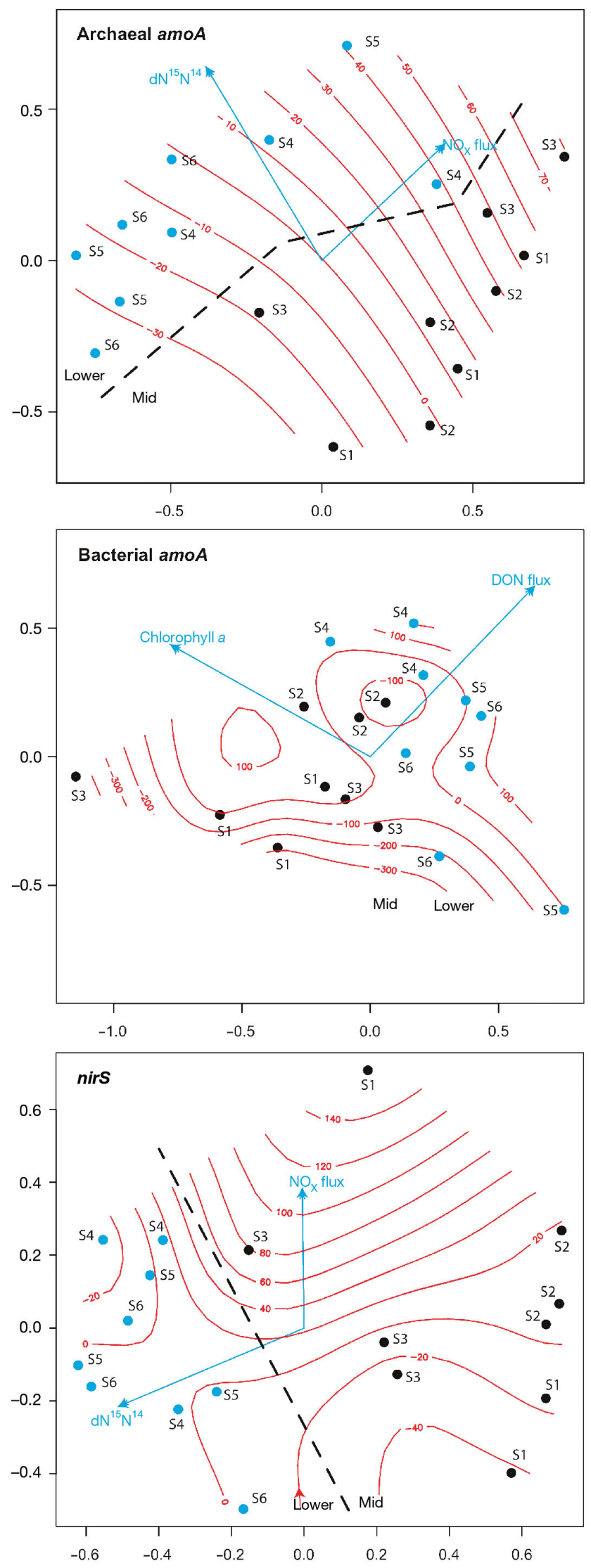

responding nutrient flux data revealed a number of significant relationships. Archaeal amoA and nirS profiles were significantly related to $\mathrm{NO}_{\mathrm{x}}$ flux $\left(\mathrm{r}^{2}=\right.$ $0.44, p=0.006$ and $r^{2}=0.41, p=0.016$, respectively), whilst bacterial amoA profiles were significantly related to DON flux $\left(\mathrm{r}^{2}=0.41, \mathrm{p}=0.023\right)$.

Stepwise linear regression analysis of nutrient flux data and QPCR abundances demonstrated that $\mathrm{O}_{2}$ flux $(\mathrm{p}<0.05)$ and bacterial abundance $(\mathrm{p}<0.05)$ together accounted for $41 \%$ of the variation in $\mathrm{NH}_{4}$ flux. $\mathrm{NH}_{4}$ flux $(\mathrm{p}<0.001)$ and AOB abundance $(\mathrm{p}<$ 0.01 ) accounted for $73 \%$ of the variation in $\mathrm{NO}_{\mathrm{x}}$ flux.

\section{DISCUSSION}

The objective of the present study was to compare and contrast the structure and abundance of different nitrogen cycling microbial groups and, where possible, relate these populations to environmental factors and processes.

\section{Spatial and temporal variability in sediment parameters and microbial abundance}

The Derwent Estuary is a highly variable environment, and large variation in a number of factors measured $(\% \mathrm{C}, \% \mathrm{~N}, \mathrm{chl} a$ and DO) made it difficult to detect significant differences between estuary sections or sampling times. However, significant differences were detected for $\mathrm{C}: \mathrm{N}$ ratios and stable isotope signatures, which are a sensitive indicator of $\mathrm{OM}$ sources (Peterson 1999). Relatively depleted $\delta^{13} \mathrm{C}$ and $\delta^{15} \mathrm{~N}$ values in the mid estuary, corresponding with relatively high $\mathrm{C}: \mathrm{N}$ ratios, indicated a more 'terrestrial' (C3) source of OM, which is likely to include fibre from the paper mill (Oakes et al. 2010). In contrast, $\delta^{13} \mathrm{C}$ and $\delta^{15} \mathrm{~N}$ values in the lower estuary were more enriched and $\mathrm{C}: \mathrm{N}$ ratios were lower, indicating

Fig. 6. Multi-dimensional scaling analysis of mean (site) archaeal amoA, bacterial amoA and nirS, T-RFLP profiles, showing sites in the mid estuary (black) and lower Derwent Estuary (blue) separated by a dashed line where there was a significant difference between sections. Significant relationships $(\mathrm{p}<0.05)$ between environmental variables and ordination are shown as vectors whilst significant relationships between nutrient flux and ordination are also shown as topography with rate of nutrient flux shown at each of the contours $\left(\mathrm{NO}_{\mathrm{x}}\right.$, archaeal amoA and nirS; dissolved organic nitrogen [DON], bacterial amoA). Stress values for nirS, archaeal $a m o A$ and bacterial $a m o A$ ordination were 16.0, 13.7 and $10.4 \%$, respectively 
a greater contribution of marine phytoplankton. These differences in OM sources are likely to affect the rate of mineralisation by heterotrophic microorganisms. Due to its low C:N ratio, OM in the lower estuary is more easily mineralised to ammonia (more labile) and, thereby, supports increased growth of heterotrophic organisms (Touratier et al. 1999). This is reflected in the higher abundance of both bacterial and archaeal 16S in the lower estuary, suggesting a higher biomass of heterotrophic organisms.

Denitrifier numbers reported for other estuarine environments vary by over an order of magnitude $\left(10^{5}\right.$ to $10^{7}$ copies g ${ }^{-1}$ DW sediment; Smith et al. 2007, Mosier \& Francis $2011 ; 10^{8}$ to $10^{9}$ copies ${ }^{-1}$ DW sediment; Abell et al. 2010), whilst there is also significant variation in numbers of AOA and AOB (Araki et al. 2004, Mosier \& Francis 2008, Santoro et al. 2008, Abell et al. 2010, Bernhard et al. 2010). The numbers of organisms detected in the present study were in line with those described in these previous studies.

Using multiple linear regression, we demonstrated that factors related to the nature of OM were the best predictors of variability in abundance of all the genes assayed, and are therefore most likely to affect the abundance of different microbial groups. A portion of the variability of each gene was unaccounted for by the factors examined in this study, indicating that other parameters are important determinants of abundance for the targeted microbial groups. However, for most genes a large portion of the variability was described by 2 factors. The best indicators $\left(\delta^{15} \mathrm{~N}\right.$, $\% \mathrm{C}$ and $\% \mathrm{~N}$ ) related to the lability and source of $\mathrm{OM}$ in the sediment, suggesting that the ease with which organic substrates are easily mineralized by microorganisms is a key determinant of nitrifier, denitrifier and total microbial abundance in the Derwent Estuary.

\section{Variation in sediment microbial community composition}

A study at the landscape scale has indicated that soil chemistry can account for 43 to $85 \%$ of the spatial variation in abundance of soil $\mathrm{N}$-cycling communities (Bru et al. 2011). Similarly, the closely related Ncycling communities in the present study are likely to be influenced by individual site sediment parameters. This suggests an importance of individual site histories in shaping microbial communities, in line with the conclusions of a previous study in the Derwent Estuary (Oakes et al. 2011). These site-specific community patterns complement the findings of large-scale studies of beta diversity that have demonstrated the role of gross habitat in defining the total microbial community and the composition of specific functional groups of microbes (Lozupone \& Knight 2007, Auguet et al. 2010, Jones \& Hallin 2010, Gubry-Rangin et al. 2011, Biller et al. 2012, Fernàndez-Guerra \& Casamayor 2012, Cao et al. 2013).

T-RFLP analysis of the different communities in the present study demonstrated a relatively diverse community of bacteria, archaea and denitrifiers compared with the 2 nitrifier groups (Table S3). The trend of relatively higher diversity of AOA compared with AOB was consistent with previous studies (Beman \& Francis 2006, Mosier \& Francis 2008).

With the exception of the AOA, there was no temporal effect on community composition. This result is surprising given the significant changes in environmental conditions in the estuary between sampling times (Table 1), and contrasts with a previous study of estuarine sediment from a sub-tropical estuary that demonstrated a significant temporal effect on nirS but not AOA (Abell et al. 2010).

Multivariate analysis of T-RFLP data from the present study demonstrated a significant spatial effect on the different microbial communities in the sediment (Table 2). All the microbial groups assessed demonstrated a highly site-specific community structure (i.e. all 6 sites had distinct populations that were stable over time). There was a significant difference in the compostion of the AOA and nirS communities between the mid and lower estuary, but no other groups showed a similar large-scale spatial effect whereby sites within the different estuary sections were more similar. Over the course of the study there was significantly higher salinity in the lower estuary. Previous studies have shown salinity to be a strong factor in the partitioning of microbial communities including total microbes (16S rRNA gene), nitrifiers (amoA gene) and denitrifiers (nirS and nirK genes) (Lozupone \& Knight 2007, Abell et al. 2010, Bernhard et al. 2010, Jones \& Hallin 2010, Biller et al. 2012, Fernàndez-Guerra \& Casamayor 2012, Cao et al. 2013). In the present study, salinity was significantly related to the composition of bacterial 16S, AOA and nirS communities. The lack of a significant relationship between salinity and archaea or AOB in the present study may reflect the relatively small salinity range encompassed within this study (24 to 35 ; Table 1 ) compared with other studies.

In addition to a significant relationship with salinity, $\delta^{15} \mathrm{~N}$ or $\delta^{13} \mathrm{C}$ was strongly related to the community structure of all groups except the $\mathrm{AOB}$, reflecting the consistent trend of increasing sediment $\delta^{15} \mathrm{~N}$ 
and $\delta^{13} \mathrm{C}$ down the estuary, across all 3 time points (Table S2). This relationship is shown in the ordination plots (Figs. $5 \& 6$ ), illustrating a role of OM source and lability in shaping these microbial communities. These relationships suggest that the type of $\mathrm{OM}$ and its lability are important in not only gene abundance, as described above, but also in shaping microbial community composition. Similarly, a significant relationship between $\mathrm{C}: \mathrm{N}$, an indicator of $\mathrm{OM}$ lability, and nirS community composition was demonstrated in San Francisco Bay, USA (Mosier \& Francis 2011). Furthermore, Oakes et al. (2011) demonstrated that the quantity and lability of $\mathrm{OM}$ in the Derwent Estuary influenced denitrification rates. Labile OM initially increased denitrification, but the presence of refractory OM subsequently suppressed denitrification through microbial competition for nitrogen (Oakes et al. 2011).

Examination of T-RFLP profiles suggests that AOB diversity and evenness was negatively associated with $\mathrm{O}_{2}$ flux whilst ordination of AOB profiles indicated a relationship with chlorophyll. The relationship between chl a content and AOB phylotype composition may relate to competition between algae and $\mathrm{AOB}$ for inorganic nitrogen as has been previously suggested for algal-colonised sediments, with algae having faster growth and $\mathrm{N}$ uptake rates than nitrifiers (Risgaard-Petersen et al. 2004). Alternatively, changes in redox gradients in sediments, associated with algal photosynthesis, may affect the composition of sediment AOB communities as has been suggested previously (Abell et al. 2011).

The similarity in assemblage structure between the different microbial guilds (Table S5 in the Supplement) indicates that the composition may be shaped by similar factors, for example the flow of inorganic nitrogen in the system. Overall, these results suggest that patterns of beta diversity between different functional groups (genes) are related and hint at common drivers of community structure.

\section{Nutrient fluxes and related microbial communities}

The positive fluxes of both $\mathrm{NO}_{\mathrm{x}}$ and $\mathrm{NH}_{4}$ at $\mathrm{T} 1$ suggest that mineralisation of OM exceeded nitrification, which, in turn, exceeded denitrification. However, at the subsequent 2 sampling times the majority of sites (10/12) showed a negative flux of $\mathrm{NO}_{\mathrm{x}}$ indicating that the rate of denitrification exceeded the rate of nitrification. Likewise, the rate of mineralisation exceeded that of nitrification at most sites (7/12). There was a strong positive relationship between
$\mathrm{NO}_{\mathrm{x}}$ and $\mathrm{NH}_{4}{ }^{+}$fluxes (Fig. S1), suggesting that nitrification was strongly coupled to $\mathrm{NH}_{4}{ }^{+}$production resulting from $\mathrm{OM}$ mineralisation. We assume that there was negligible anammox in the estuary as we were unable to detect 16S rRNA or hzsA genes associated with anammox organisms using PCR in the estuary (results not shown).

Using multiple linear regression we were able to explain a significant degree of the variablility in nutrient fluxes. Fluxes of $\mathrm{NH}_{4}{ }^{+}$were explained using a combination of $\mathrm{O}_{2}$ flux and bacterial abundance, suggesting that greater numbers of bacteria combined with increased respiration rate (greater uptake of oxygen) resulted in elevated mineralisation $\left(\mathrm{NH}_{4}{ }^{+}\right.$ flux). Subsequently, the model that best accounted for $\mathrm{NO}_{\mathrm{x}}$ flux was a combination of $\mathrm{NH}_{4}{ }^{+}$flux and AOB abundance, suggesting that $\mathrm{NO}_{\mathrm{x}}$ production was strongly coupled to mineralisation and that the AOB and not the AOA were responsible for the majority of nitrification in the Derwent Estuary. Whilst a number of studies have shown AOA to be the dominant $a m o A$ type, it is not clear whether they are responsible for nitrification in these environments. A study of Plum Island Sound, Massachusetts, USA, did not support a major contribution of AOA to nitrification, despite AOA outnumbering AOB (Bernhard et al. 2005), whilst a study in terrestrial systems suggest complex niche specialisation between $\mathrm{AOA}$ and AOB (Bru et al. 2011), with AOA likely to actively nitrify under specific environmental conditions.

The portion of the variability unexplained by these models may relate to other factors unaccounted for here, such as competition with algae for nutrients.

We also investigated whether abundance or composition of specific communities was related to the flux of different nutrients. The relationship between $\mathrm{AOA}$ and nirs community structure and $\mathrm{NO}_{\mathrm{x}}$ flux (Fig. 6), whilst unrelated to estuarine section (mid or lower), suggests that these 2 groups are related to $\mathrm{NO}_{\mathrm{x}}$ flux. This relationship may be explained by the production of $\mathrm{NO}_{x}$ by AOA and its subsequent utilization by nirS-type denitrifiers, with increasing production and utilisation being associated with community structure as a consequence of the substrate affinity of different members. However, the production of $\mathrm{NO}_{\mathrm{x}}$ by AOA contradicts the notion that $\mathrm{AOB}$ are responsible for the bulk of ammonia oxidation, highlighting the need for further study of these groups in the Derwent Estuary.

In summary, these data suggest that highly specific communities have developed at each of the sites examined and the lability and quantity of OM inputs affect the composition, abundance and activity of key 
$\mathrm{N}$-cycling microbes in the estuary. As suggested by Oakes et al. (2011), the activity of N-cycling microbial communities is therefore likely to change in response to changes in the quantity and lability of OM input. This would alter the way in which nutrients are cycled, possibly resulting in increased export of nitrogen to the open ocean in response to increased organic nitrogen loads to the estuary, as suggested previously (Fulweiler et al. 2007).

\section{CONCLUSIONS}

Estuaries are highly complex systems subject to multiple inputs and outputs of key nutrients such as nitrogen, the nutrient most critical for determining productivity. Microbial communities are central to regulating the uptake and loss of nitrogen. In the present study we sought to identify relationships between the abiotic parameters that vary within the estuary and the abundance and diversity of microbes in general, and microbial nitrifiers and denitrifiers in particular.

By examining the spatial and temporal factors that relate the different groups of organisms to each other, as well as the fluxes of nutrients that are associated with their activity, we have been able to demonstrate that, under small variations in salinity, factors related to the nature of sediment OM are strongly related to the abundance and composition of microbial groups and communities in the Derwent Estuary. It is clear that fluxes of nutrients, whilst highly variable, are related to both the composition of the associated microbial communities and their abundance, which in turn is related to the nature of organic material in the estuary. Experiments in which organic materials of differing lability are introduced to systems containing microbial communities of known composition will further elucidate the relationships between OM signature and community composition as well as community activity and adaptability to changes in nutrient quality and load. The ecological niches across which these communities are studied are also clearly important in accounting for the diversity of organisms in the estuary, with microbial communities specific to individual sites apparently being strongly influenced by local sediment geochemistry and site history. Experiments combining theoretical modeling of these processes (van de Leemput et al. 2011) with analysis of the underlying microbial communities will likely yield further insights into the role that microbial communities play in determining the cycling of nitrogen in estuarine sediments.
Acknowledgements. We thank Andy Revill and Rebecca Esmay for nitrogen and carbon analyses and Rick Smith for assistance with the figures. This work was partially funded under an Australian Research Council Linkage grant (LP0775365) awarded to D.J.R. and B.D.E. with the industry support of the Derwent Estuary Program and Norske Skog, Boyer.

\section{LITERATURE CITED}

Abell GCJ, Revill AT, Smith C, Bissett AP, Volkman JK, Robert SS (2010) Archaeal ammonia oxidizers and nirStype denitrifiers dominate sediment nitrifying and denitrifying populations in a subtropical macrotidal estuary. ISME $\mathrm{J}$ 4:286-300

> Abell GCJ, Banks J, Ross DJ, Keane JP, Robert SS, Revill AT, Volkman JK (2011) Effects of estuarine sediment hypoxia on nitrogen fluxes and ammonia oxidizer gene transcription. FEMS Microbiol Ecol 75:111-122

Anderson MJ, Gorley RN, Clarke KR (2008) Permanova+ for primer: guide to software and statistical methods. PRIMER-E, Plymouth

Araki N, Yamaguchi T, Yamazaki S, Harada H (2004) Quantification of $a m o A$ gene abundance and their amoA mRNA levels in activated sludge by real-time PCR. Water Sci Technol 50:1-8

Auguet JC, Barberan A, Casamayor EO (2010) Global ecological patterns in uncultured archaea. ISME J 4:182-190

Beman JM, Francis CA (2006) Diversity of ammonia-oxidizing archaea and bacteria in the sediments of a hypernutrified subtropical estuary: Bahia del Tóbari, Mexico. Appl Environ Microbiol 72:7767-7777

Bernhard AE, Donn T, Giblin AE, Stahl DA (2005) Loss of diversity of ammonia-oxidizing bacteria correlates with increasing salinity in an estuary system. Environ Microbiol 7:1289-1297

Bernhard AE, Landry ZC, Blevins A, de la Torre JR, Giblin AE, Stahl DA (2010) Abundance of ammonia-oxidizing archaea and bacteria along an estuarine salinity gradient in relation to potential nitrification rates. Appl Environ Microbiol 76:1285-1289

> Biller SJ, Mosier AC, Wells GF, Francis CA (2012) Global biodiversity of aquatic ammonia-oxidizing archaea is partitioned by habitat. Front Microbiol 3:252

Braker G, Fesefeldt A, Witzel KP (1998) Development of PCR primer systems for amplification of nitrite reductase genes (nirK and nirS) to detect denitrifying bacteria in environmental samples. Appl Environ Microbiol 64:3769-3775

Bru D, Ramette A, Saby NPA, Dequiedt S and others (2011) Determinants of the distribution of nitrogen-cycling microbial communities at the landscape scale. ISME J 5:532-542

> Cao H, Auguet JC, Gu JD (2013) Global ecological pattern of ammonia-oxidizing archaea. PLoS ONE 8:e52853

Cébron A, Berthe T, Garnier J (2003) Nitrification and nitrifying bacteria in the lower Seine River and estuary (France). Appl Environ Microbiol 69:7091-7100

Cloern JE (2001) Our evolving conceptual model of the coastal eutrophication problem. Mar Ecol Prog Ser 210: 223-253

> Dang H, Zhang X, Sun J, Li T, Zhang Z, Yang G (2008) Diversity and spatial distribution of sediment ammonia-oxidizing crenarchaeota in response to estuarine and environmental gradients in the Changjiang Estuary and East China Sea. Microbiology 154:2084-2095

> Erguder TH, Boon N, Wittebolle L, Marzorati M, Verstraete W (2009) Environmental factors shaping the ecological niches of ammonia-oxidizing archaea. FEMS Microbiol Rev 33:855-869 
Eyre BD, Ferguson AJP (2005) Benthic metabolism and nitrogen cycling in a subtropical east Australian estuary (Brunswick): temporal variability and controlling factors. Limnol Oceanogr 50:81-96

Fernàndez-Guerra A, Casamayor EO (2012) Habitat-associated phylogenetic community patterns of microbial ammonia oxidizers. PLoS ONE 7:e47330

Francis CA, O'Mullan GD, Ward BB (2003) Diversity of ammonia monooxygenase $(a m o A)$ genes across environmental gradients in Chesapeake Bay sediments. Geobiology 1:129-140

Francis CA, Roberts KJ, Beman JM, Santoro AE, Oakley BB (2005) Ubiquity and diversity of ammonia-oxidizing archaea in water columns and sediments of the ocean. Proc Natl Acad Sci USA 102:14683-14688

Fulweiler RW, Nixon SW, Buckley BA, Granger SL (2007) Reversal of the net dinitrogen gas flux in coastal marine sediments. Nature 448:180-182

> Giovannoni SJ, DeLong EF, Olsen GJ, Pace NR (1988) Phylogenetic group-specific oligodeoxynucleotide probes for identification of single microbial cells. J Bacteriol 170: 720-726

> Glud RN, Gundersen JK, Revsbech NP, Jorgensen BB, Huttel $M$ (1995) Calibration and performance of the stirred flux chamber from the benthic lander Elinor. Deep-Sea Res Part I 42:1029-1042

Green G, Coughanowr C (2003) State of the Derwent Estuary: a review of pollution sources, loads and environmental quality data from 1997-2003. Derwent Estuary Program, DPIWE, Tasmania

> Gubry-Rangin C, Hai B, Quince C, Engel M and others (2011) Niche specialization of terrestrial archaeal ammonia oxidisers. Proc Natl Acad Sci USA 108:21206-21211

Harris GP, Batley G, Fox D, Hall D and others (1996) Port Phillip Bay environmental study: final report. CSIRO, Dickson, ACT

> Hauben L, Vauterin L, Swings J, Moore ERB (1997) Comparison of 16S ribosomal DNA sequences of all Xanthomonas species. Int J Syst Bacteriol 47:328-335

> Jones CM, Hallin S (2010) Ecological and evolutionary factors underlying global and local assembly of denitrifier communities. ISME J 4:633-641

> Jurgens G, Lindstrom K, Saano A (1997) Novel group within the kingdom Crenarchaeota from boreal forest soil. Appl Environ Microbiol 63:803-805

Kenkel NC, Orloci L (1986) Applying metric and nonmetric multidimensional scaling to some ecological studies: some new results. Ecology 67:919-928

Lozupone CA, Knight R (2007) Global patterns in bacterial diversity. Proc Natl Acad Sci USA 104:11436-11440

Marchesi JR, Sato T, Weightman AJ, Martin TA, Fry JC, Hiom SJ, Wade WG (1998) Design and evaluation of useful bacterium-specific PCR primers that amplify genes coding for bacterial 16S rRNA. Appl Environ Microbiol 64:795-799

McCook LJ (1999) Macroalgae, nutrients and phase shifts on coral reefs: scientific issues and management consequences for the Great Barrier Reef. Coral Reefs 18: 357-367

Middelburg JJ, Klaver G, Nieuwenhuize J, Wielemaker A, de Haas W, Vlug T, van der Nat JFWA (1996) Organic matter mineralization in intertidal sediments along an estuarine gradient. Mar Ecol Prog Ser 132:157-168

Minchin PR (1987) An evaluation of the relative robustness of techniques for ecological ordination. Plant Ecol 69:89-107

> Mosier AC, Francis CA (2008) Relative abundance and diversity of ammonia-oxidizing archaea and bacteria in the San Francisco Bay estuary. Environ Microbiol 10:3002-3016

Editorial responsibility: Tom Battin,

Vienna, Austria
Mosier AC, Francis CA (2011) Denitrifier abundance and activity across the San Francisco Bay estuary. Environ Microbiol Rep 2:667-676

> Nicol GW, Leininger S, Schleper C, Prosser JI (2008) The influence of soil $\mathrm{pH}$ on the diversity, abundance and transcriptional activity of ammonia oxidizing archaea and bacteria. Environ Microbiol 10:2966-2978

Oakes JM, Eyre BD, Ross DJ, Turner SD (2010) Stable isotopes trace estuarine transformations of carbon and nitrogen from primary- and secondary-treated paper and pulp mill effluent. Environ Sci Technol 44:7411-7417

Oakes JM, Eyre BD, Ross DJ (2011) Short-term enhancement and long-term suppression of denitrification in estuarine sediments receiving primary- and secondary-treated paper and pulp mill discharge. Environ Sci Technol 45: 3400-3406

Peterson BJ (1999) Stable isotopes as tracers of organic matter input and transfer in benthic food webs: a review. Acta Oecol 20:479-487

Philippot L, Hallin S (2005) Finding the missing link between diversity and activity using denitrifying bacteria as a model functional community. Curr Opin Microbiol 8: 234-239

Risgaard-Petersen N, Nicolaisen MH, Revsbech NP, Lomstein BA (2004) Competition between ammonia-oxidizing bacteria and benthic microalgae. Appl Environ Microbiol 70 : 5528-5537

Rotthauwe JH, Witzel KP, Liesack W (1997) The ammonia monooxygenase structural gene $a m o A$ as a functional marker: molecular fine-scale analysis of natural ammoniaoxidizing populations. Appl Environ Microbiol 63: 4704-4712

> Sahan E, Muyzer G (2008) Diversity and spatio-temporal distribution of ammonia-oxidizing Archaea and Bacteria in sediments of the Westerschelde estuary. FEMS Microbiol Ecol 64:175-186

Santoro AE, Francis CA, de Sieyes NR, Boehm AB (2008) Shifts in the relative abundance of ammonia-oxidizing bacteria and archaea across physicochemical gradients in a subterranean estuary. Environ Microbiol 10:1068-1079

Seitzinger S, Harrison JA, Böhlke JK, Bouwman AF and others (2006) Denitrification across landscapes and waterscapes: a synthesis. Ecol Appl 16:2064-2090

Smith CJ, Nedwell DB, Dong LF, Osborn AM (2007) Diversity and abundance of nitrate reductase genes (narG and napA), nitrite reductase genes (nirS and nrfA), and their transcripts in estuarine sediments. Appl Environ Microbiol 73:3612-3622

Stehr G, Böttcher B, Dittberner P, Rath G, Koops HP (1995) The ammonia-oxidizing nitrifying population of the River Elbe estuary. FEMS Microbiol Ecol 17:177-186

Strickland JD, Parsons TR (1972) A practical handbook of seawater analysis. Fisheries Research Board of Canada, Ottawa

> Tengberg A, Stahl H, Gust G, Muller V, Arning U, Andersson $\mathrm{H}$, Hall POJ (2004) Intercalibration of benthic flux chambers I. Accuracy of flux measurements and influence of chamber hydrodynamics. Prog Oceanogr 60:1-28

> Touratier F, Legendre L, Vézina A (1999) Model of bacterial growth influenced by substrate $\mathrm{C}: \mathrm{N}$ ratio and concentration. Aquat Microb Ecol 19:105-118

van de Leemput IA, Veraart AJ, Dakos V, de Klein JJM, Strous M, Scheffer M (2011) Predicting microbial nitrogen pathways from basic principles. Environ Microbiol 13: 1477-1487

Zann IP (1995) State of the marine environment report for Australia. Great Barrier Reef Marine Park Authority, Townsville 